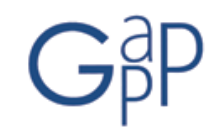

GESTIÓN Y ANÁLISIS DE POLÍTICAS PÚBLICAS, Nueva Época, - N. 15, enero-junio 2016 - ISSN: 1989-8991

\title{
Criterios para la presentación y publicación de originales
}

Gestión y Análisis de Políticas Públicas (GAPP) es la revista pionera y más significativa en España dentro de su especialidad. Editada por el Instituto Nacional de Administración Pública (INAP), se ha distinguido por impulsar los estudios interdisciplinares en la materia y el análisis de experiencias y casos de especial interés para los profesionales de las administraciones públicas. Con ello ha contribuido a dinamizar el debate sobre los modelos teóricos y empíricos de gestión pública, así como sobre los procesos de transformación de los escenarios de acción gubernamental. A partir del año 2009 ha emprendido una Nueva Época, buscando un mayor impacto y proyección internacional. No obstante, fiel a sus señas de identidad, continúa persiguiendo los objetivos de potenciar la reflexión analítica en el campo de las políticas públicas y de priorizar la aplicabilidad y utilidad de los estudios sobre las mismas.

\section{CONDICIONES DE PRESENTACIÓN PARA SU PUBLICACIÓN EN LA REVISTA}

- Los autores deberán enviar un archivo de cada original a la dirección de correo electrónico de la Secretaría de la revista: revistagapp@inap.es

- Los trabajos pueden ser enviados en español o en inglés.

- Solamente serán sometidos al proceso de evaluación aquellos trabajos que se ajusten a los criterios formales exigidos.

\section{EVALUACIÓN Y ACEPTACIÓN DE ORIGINALES}

- La Secretaría del Consejo de Redacción remitirá al autor acuse de recibo de su trabajo. Asimismo, en un plazo que no excederá de un mes desde la recepción del original, le comunicará si el trabajo ha sido admitido al proceso de evaluación o si se ha dispuesto su rechazo por no cumplir los criterios formales o editoriales. La fecha de admisión a la evaluación se considerará como "fecha de recepción”, y así constará en la publicación.

- Todos los trabajos que cumplan los criterios formales y editoriales serán sometidos a un proceso de evaluación anónima por dos expertos externos. Si existiese contradicción entre los informes de los dos evaluadores, se procederá a una tercera evaluación que se considerará definitiva.

- El texto de los artículos que se entregue a los evaluadores no incluirá expresiones que hagan referencia a la identidad del autor o autores.

- Bajo ninguna circunstancia se revelará la identidad de los evaluadores y sus informes motivados serán decisivos a la hora de que el Consejo de Redacción entienda procedente o no la publicación de los trabajos.

- En un plazo máximo de seis meses (que podrá ampliarse en circunstancias extraordinarias) a partir de la fecha de admisión a la evaluación del trabajo, el Consejo de Redacción remitirá al autor los resultados de la misma que podrán ser: a) Publicable en la versión presentada; b) publicable con modificaciones. Se acepta, pero se solicita al autor que corrija las revisiones que se especifican en el informe de evaluación. Las modificaciones a realizar pueden ser formales o de contenido; c) no publicable; y d) se considera que el texto es de alta calidad y rigor científico, pero inapropiado para la línea editorial de la revista Gestión y Análisis de Políticas Públicas. Al autor se le indicará, en su caso, el tiempo de que dispone para realizar las correcciones pertinentes, solicitándole además un breve informe explicativo donde se detallen los cambios introducidos y/o la justificación de prescindir de las modificaciones. El Consejo de Redacción se reserva el derecho de efectuar correcciones gramaticales y sugerencias de estilo en los trabajos evaluados. La fecha de entrega del artículo corregido, junto al informe respectivo, se considerará como "fecha de aceptación” que constará en la publicación. 


\section{CRITERIOS FORMALES DE PRESENTACIÓN DE ORIGINALES}

- Los trabajos deben ser presentados exclusivamente en formato electrónico, en procesador de textos Word for Windows, en tamaño DIN A4, a un espacio y medio atendiendo a márgenes normalizados a cada página. No se establece una extensión máxima, pero se sugiere que los trabajos propuestos para la sección de Estudios no excedan las 10.000 palabras, incluyendo notas y referencias bibliográficas; y que los trabajos considerados Experiencias y Casos no excedan las 8.000 palabras, incluyendo notas y referencias bibliográficas.

- En archivo aparte el autor o autores deben enviar sus datos completos (institución a la que están adscritos, dirección postal, dirección electrónica y teléfono) y una breve reseña curricular (máximo 100 palabras) en la que incluyan grado académico, institución a la que pertenecen, puestos profesionales relevantes, líneas de investigación y principales publicaciones.

- El título del artículo deberá presentarse en español y en inglés. Se recomienda que en español no exceda de 100 caracteres (incluyendo espacios).

- Cada trabajo debe acompañarse de un resumen de no más de 200 palabras, tanto en español como en inglés, y de una serie de palabras clave (máximo siete), preferentemente no incluidas en el título, e igualmente en español y en inglés.

- Los gráficos, tablas, cuadros, mapas y otros dibujos e imágenes llevarán un título, deberán integrarse dentro del texto e ir numerados consecutivamente. Cada uno de ellos indicará su fuente de procedencia. Para facilitar el trabajo de maquetación, las imágenes se insertarán en el texto, pero también serán adjuntadas en carpeta aparte en tamaño y resolución web.

- Las citas en el texto deben hacerse entre paréntesis por autor y año, seguido de la página o páginas citadas (Lindblom, 1959: 79). Si se cita el trabajo de dos autores deberá incluirse el apellido de los dos unidos por la conjunción "y". Si se trata de tres o más autores, es suficiente citar el primer autor seguido de et al. Si se citan varios trabajos de un autor o conjunto de autores correspondientes a un mismo año, debe añadirse las letras $a, b$, c..., después del año indicado, tanto en el texto como en el apartado final de "Referencias bibliográficas y documentales". Asimismo, en este apartado sí deben figurar todos los autores no mencionados al hacerse uso de et al en las citas.

- Las notas deben ir a pie de página y el autor debe asegurarse de que estas notas y las citas incluidas en el texto coincidan con los datos aportados en la bibliografía final.

- Las referencias a prensa deberán incluir, cuando sea pertinente, el título del artículo que se cita entre comillas y, en todo caso, el nombre de la publicación en letra cursiva, la fecha de publicación y, si procede, la página o páginas. Por ejemplo:

The Economist, 27 de enero de 2008.

Toner, R., "New Deal Debate for a New Era”, The New York Times, 1 de agosto de 2007.

El País, 9 de marzo de 2002: 28.

- Al final del texto -en un apartado titulado Referencias bibliográficas y documentales- debe incluirse, por orden alfabético, el listado completo de la bibliografía y otras fuentes. Se deben seguir los siguientes formatos:

Libro:

Meny, I. y Thoenig, J.C. (1992), Les politiques publiques. París: PUF.

Weber, M. (1964 [1922]), Economía y sociedad. México D.F.: Fondo de Cultura Económica.

Si la publicación es electrónica deberá indicarse el DOI o el URL donde se encuentra disponible el texto.

Demetriades, J., ed., (2009), Gender and Governance, Brighton: Bridge. En línea: <http://www.bridge.ids.ac.uk/ reports/Governance_SRC_final.doc> (consulta: 14 abril 2011).

\section{Trabajo en un libro colectivo:}

Sabatier, P.A. y Jenkins-Smith, H.C. (1999), “The Advocacy Coalition Framework: An Assessment”, en P.A. Sabatier, ed., Theories of Policy Process. Boulder: Westview Press.

Artículo:

Goodsell, C. (2006), “A New Vision for Public Administration”, Public Administration Review, 66(5): 623-635. 
Lombardo, E. y Meier, P. (2006), "Gender Mainstreaming in the EU. Incorporating a Feminist Reading?", European Journal of Women Studies, 13(2): 151-166. DOI: 10.1177/1350506806062753 (consulta: 14 abril 2011).

Página web: Si la publicación está disponible exclusivamente en internet.

Schmitter, P.C. (2004), "On Democracy in Europe and the Democratization of Europe", Documentos de Trabajo Política y Gestión 1. Madrid: Universidad Carlos III de Madrid. En línea: <http://www.uc3m.es/uc3m/dpto/CPS/ schmitter.pdf> (consulta: 14 abril 2011).

\section{Todas las referencias bibliográficas deberán acompañarse de su nº DOI, si lo tuviesen.}

- Se recomienda evitar el uso de palabras en idioma distinto al español y de neologismos innecesarios. En caso de que su uso fuera necesario por no existir traducción satisfactoria al español, se pondrá en letra cursiva.

- La primera vez que se utilicen siglas o acrónimos deberán escribirse entre paréntesis precedidos por el nombre completo.

- A fin de resolver las dudas que pudieran surgir acerca del cumplimiento de las normas de publicación, los autores pueden tomar como referencia los criterios de la American Psychological Association (APA).

\section{Estructuración del artículo}

Todos los artículos deberán seguir el modelo de redacción IMRyD (Introducción, Metodología, Resultados y Discusión).

\section{DERECHOS Y OBLIGACIONES DE LOS AUTORES}

- Los autores ceden al INAP los derechos correspondientes al trabajo publicado en la revista, incluidos, con carácter exclusivo e ilimitado, los derechos a reproducir y distribuir el texto en cualquier formato o soporte (impresión, medios electrónicos o cualquier otra), además de los de traducción a cualquier otra lengua, sin perjuicio de las normas particulares o locales aplicables.

- El autor deberá enviar, junto al original, el formulario de declaración formal que podrá descargar de la página web de la revista GAPP, debidamente cumplimentado y firmado. En la declaración constará que el contenido esencial del artículo no ha sido publicado ni se va a publicar en ninguna otra obra o revista mientras esté en proceso de evaluación en la revista $G A P P$, comprometiéndose en todo caso a comunicar de inmediato a la Dirección de la revista cualquier proyecto de publicación de dicho texto. 